\title{
New genus, three new species and new records of Herpyllobiidae Hansen, 1892 (Crustacea, Copepoda), parasites of polychaetes from Antarctica
}

\author{
PABLO J. LÓPEZ-GONZÁLEZ ${ }^{1}$, JOSÉ BRESCIANI ${ }^{2}$ and MERCEDES CONRADI ${ }^{1}$ \\ ${ }^{1}$ Biodiversidad y Ecología de Invertebrados Marinos, Departamento de Fisiología y Zoología, Facultad de Biología, \\ Universidad de Sevilla, Apdo. 1095, 41080-Sevilla, Spain. E-mail: pjlopez@us.es \\ ${ }^{2}$ Department of Zoology, Royal Veterinary and Agricultural University, \\ Thorvaldsesvej 40, DK-1871 Fredericksberg C, Denmark.
}

\begin{abstract}
SUMMARY: During the Antarctic Polarstern cruises ANT XIX/3 (ANDEEP-I), XIX/5 (LAMPOS), and XXI/2 (BENDEX) new material of symbiotic copepods associated with polynoid polychaetes was collected. Here the authors present results for the highly modified family Herpyllobiidae Hansen, 1892. New records of Herpyllobius antarcticus Vanhöffen, 1913 and Herpyllobius polarsterni López-González, Bresciani and Conradi, 2000 are provided from the eastern Weddell Sea and Bouvet Island respectively. A new species of the genus Eurysilenium Sars, 1870, E. australis, is described from specimens collected at the eastern Weddell Sea. A new genus, Gottoniella gen. nov., is proposed to include two species, G. antarctica sp. nov. and G. andeepi sp. nov., described from material collected from the Weddell Sea and Scotia Arc.
\end{abstract}

Keywords: parasitic Copepoda, Herpyllobiidae, Herpyllobius, Eurysilenium, Gottoniella, Antarctica, Polynoidae.

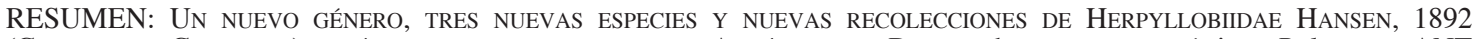
(CRUSTACEA, COPEPODA) PARÁsITOS DE POLIQUETOS DE LA ANTÁRTIDA. - Durante los cruceros antárticos Polarstern ANT XIX/3 (ANDEEP-I), XIX/5 (LAMPOS), y XXI/2 (BENDEX) se recolectó nuevo material de copépodos simbiontes asociados a poliquetos polinoidos. En este trabajo, los autores presentan los resultados correspondientes a la familia de copépodos altamente transformados Herpyllobiidae Hansen, 1892. Se recogen nuevas citas de Herpyllobius antarcticus Vanhöffen, 1913 y de Herpyllobius polarsterni López-González, Bresciani y Conradi, 2000 para el mar de Weddell oriental e isla Bouvet, respectivamente. Se describe e ilustra una nueva especie del género Eurysilenium, E. australis sp. nov., a partir de especímenes encontrados en el mar de Weddell oriental. Se propone un nuevo género, Gottoniella gen nov., para incluir dos nuevas especies, G. antarctica sp. nov. y G. andeepi sp. nov., descritas a partir de ejemplares procedentes del mar de Weddell y del Arco de Escocia.

Palabras clave: Copépodos parásitos, Herpyllobiidae, Herpyllobius, Eurysilenium, Gottoniella, Antártida, Polynoidae.

\section{INTRODUCTION}

The family Herpyllobiidae Hansen, 1892 is one of the most highly transformed families among the parasitic Copepoda, grouping a few genera of uncertain ordinal placement (see López-González and Bresciani, 2001), although the arrangement of 3 aesthetascs on the antennules of herpyllobiid copepodid stages provides evidence that the family belongs to the poecilostome copepods (Boxshall and Halsey, 2004). Three genera have been traditionally considered in this family: Herpyllobius Steenstrup and Lütken, 1861 (17 species), Eurysilenium Sars, 1870 (4 species), and the ill-defined Phallusiella LeighSharpe, 1926 (2 species). All herpyllobiids (except Herpyllobius hartmanae Lützen and Jones, 1976; see López-González and Bresciani, 2001: Table 1) parasitize polynoid polychaetes (Lützen, 1964). 
The body of adult females comprises two portions connected by a short stalk: an endosoma inside the host body with attachment and nourishment functions; and an external ectosoma carrying the genital apertures with the ovisacs (Lützen, 1964; 1966). Known adult males are minute in comparison to the female body, and are also highly transformed. The males usually remain inside the exuvia of the last copepodid stage, and they are often found in abundance close to the genital apertures of the females (see Jensen, 1900; Lützen, 1964; LópezGonzález et al., 2000: Figs. 4C and 5A). Herpyllobiid genera mainly differ from each other in the shape of the ectosoma and endosoma of mature females, and (when known) in the shape and structure of the adult male and last male copepodid (Lützen, 1964). During the recent ANDEEP-I (Antarctic Benthic Deep-Sea Biodiversity), LAMPOS (Latin American Polarstern Study), and BENDEX (Benthic Disturbance Experiment) cruises in the Scotia Sea and Weddell Sea, some specimens belonging to the highly transformed copepod family Herpyllobiidae were collected. We present new records of two known Herpyllobius species, the description of a new species of the genus Eurysilenium, and a new genus with two new species. The new genus exhibits a combination of characters unlike any other known herpyllobiid taxon, and its relationships with the other genera in the family are discussed.

\section{MATERIAL AND METHODS}

The material was collected from the Scotia Sea with the aid of a small Agassiz trawl, and in the eastern Weddell Sea using both Bottom and Agassiz trawls (Fig. 1). The specimens were sorted, photographed, labelled and fixed on board.

Specimens were removed from the host, stained with Chlorazole black E (Sigma ${ }^{\circledR}$ C-1144), dissected, and examined in lactophenol. All figures were drawn with the aid of a camera lucida on a Wild M32 stereomicroscope and a Leica DMLB differential interference microscope. Selected material was postfixed in $1 \% \mathrm{OsO}_{4}$ in $0.2 \mathrm{M}$ cacodylate buffer at pH 7.3 and subsequently critical point dried, mounted on stubs, coated with gold-palladium and observed with a Philip XL30 SEM.

The type material studied here has been deposited in the Zoologisches Institut und Zoologisches Museum, Hamburg (ZIZMH), the remaining material has been deposited in the collections of the research group "Biodiversidad y Ecología de Invertebrados Marinos" in the University of Seville (BEIM).

The following abbreviations are used in the figures: an, antenna; as, antero-ventral shield; be, bifid element; bp, bifurcate pointed process; de, denticulated triangular elements; ec, ectosoma; en, endosoma; ga, genital aperture; gs, genital swelling; hl, hair-like structures; ic, internal canal; ls, lateral

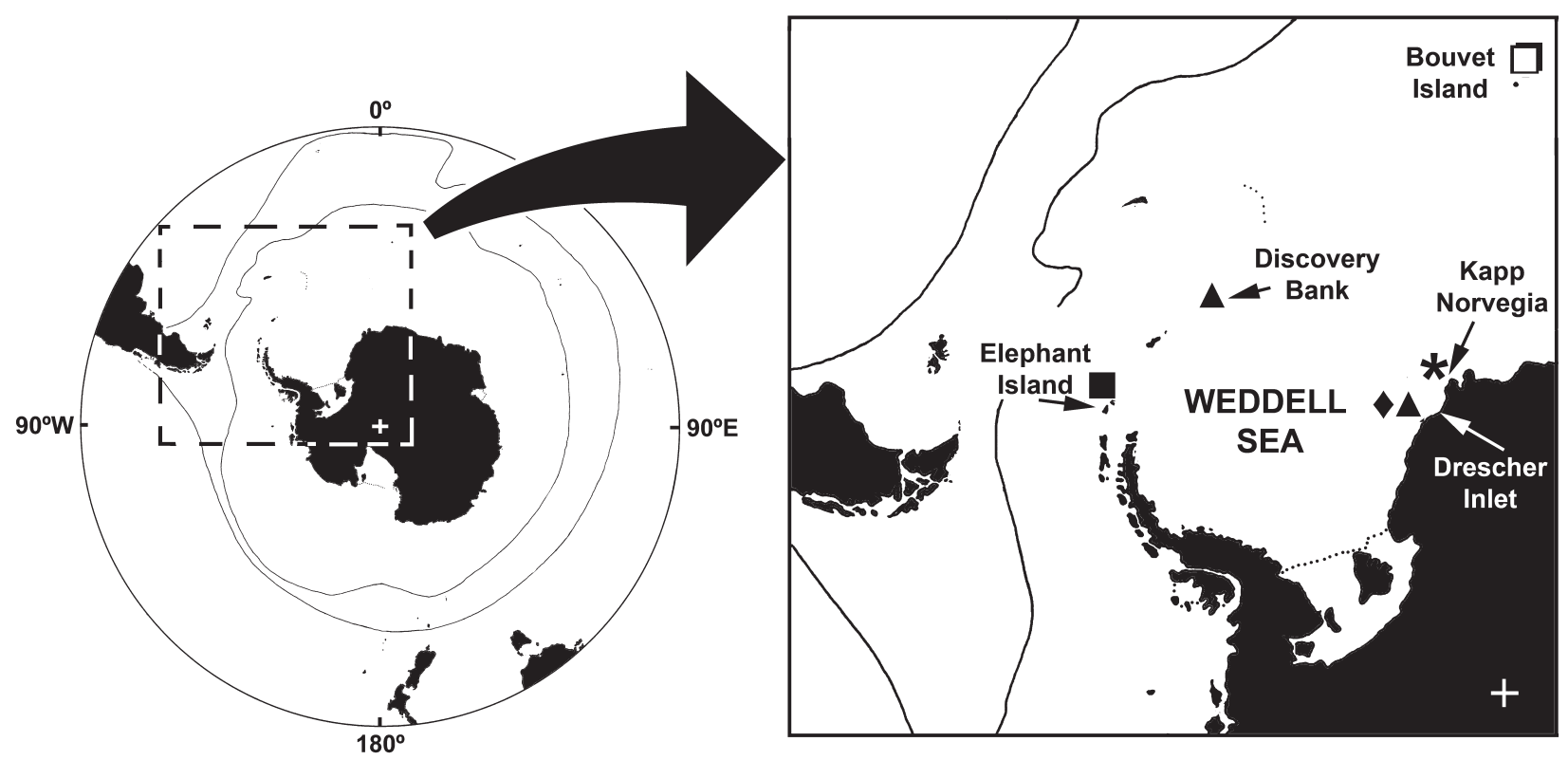

FIG. 1. - Localities where herpyllobiids were collected, coordinates and other sampling data are in the text. Herpyllobius antarcticus ( $)$,

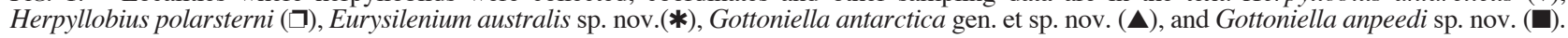


swelling; ma, male; md, mandible; ml, maxillule(?); mp, maxilliped; ms, medio-terminal swelling; mx, maxilla; ov, ovisac; pb, polychaete body; pi, polychaete intestine; po, polychaete; ps, pecten-like structure; sm, scar produced by male's attachment; sp, spermiduct (?); sr, sclerotized ring; ss, sticky secretion border.

\section{RESULTS}

Family HERPYLlOBIIDAE Hansen, 1892 Genus Herpyllobius Steenstrup and Lütken, 1861 Herpyllobius antarcticus Vanhöffen, 1913

Herpyllobius arcticus Gravier, 1912, 1913.

Material examined. BEIM (COP 207), one ovigerous female, attached to prostomium of specimen of polynoid polychaete Polyeunoa laevis McIntosh, 1885. BENDEX cruise ANT XXI/2, stn. 65/292-1, Drescher Inlet, eastern Weddell Sea, Antarctica, 72 $51.43^{\prime} \mathrm{S} 19^{\circ} 38.62^{\prime} \mathrm{W}, 576.4-597.6 \mathrm{~m}$ depth, 31 December 2003.

Remarks. This species has been reported associated with the polynoid species Polyeunoa laevis (Vanhöffen 1913, as Eniplo rhombigera) and Harmothoe gourdoni Gravier, 1911 (Gravier, 1912, 1913). In two recent accounts (López-González et al., 2000; López-González and Bresciani, 2001) this species was reported in the eastern Weddell Sea and Antarctic Peninsula.

\section{Herpyllobius polarsterni}

López-González, Bresciani and Conradi, 2000

Material examined. BEIM (COP 204-206), eight ovigerous females, attached to dorsal part of neuropodium of specimen of the polynoid polychaete Eulagisca gigantea Monro, 1939. BENDEX cruise ANT XXI/2, stn. 65/020-1, Bouvet Island, 54'36.95'S $3^{\circ} 12.42^{\prime}$ E, 549.8-553.4 m depth, 24 November 2003.

Remarks. This species was described by LópezGonzález et al. (2000) from the eastern Weddell Sea during the EASIZ II cruise and has been also reported in the Antarctic Peninsula on the same host (López-González and Bresciani, 2001).

Genus Eurysilenium Sars, 1870

Eurysilenium australis sp. nov.

(Figs. 2-8)

Material examined. ZIZMH (K 40875), holotype, one adult female, parasitizing one specimen of Polyeunoa sp. (Polynoidae), Polarstern cruise ANT XXI/2 (BENDEX), stn 65/248-1, north Kapp Norvegia, eastern Weddell Sea, Antarctica, $71^{\circ} 5.51^{\prime} \mathrm{S}$ 11 $30.46^{\prime} \mathrm{W}, 286.4 \mathrm{~m}$ depth, 23 December 2003. ZIZMH (K 40881), allotype, one adult male, with the same sampling data as the holotype. BEIM (COP 209), two adult females, two adult males, and two copepodis, with the same sampling data as the holotype.
BEIM (COP 210), two ovigerous females (with one adult male) and one young female parasitizing one specimen of Polyeunoa sp. (Polynoidae), Polarstern cruise ANT XXI/2 (BENDEX), stn 65/276-1, north Kapp Norvegia, eastern Weddell Sea, Antarctica, 71 ${ }^{\circ} 6.44^{\prime} \mathrm{S} 11^{\circ} 27.76^{\prime} \mathrm{W}, 268.4-277.2 \mathrm{~m}$ depth, 28 December 2003. BEIM (COP 211), one adult female parasitizing one specimen of Polyeunoa sp. (Polynoidae), Polarstern cruise ANT XXI/2 (BENDEX), stn 65/280-1, north Kapp Norvegia, eastern Weddell Sea, Antarctica, 71 ${ }^{\circ} 7.20^{\prime} \mathrm{S} 11^{\circ} 26.47^{\prime} \mathrm{W}, 190.8-228.4 \mathrm{~m}$ depth, 29 December 2003. Type host is deposited in ZIZMH (P 24719).

Female (Figs. 2A-E, 3-4). Adult female with ectosoma up to $2.8 \mathrm{~mm}$ in length and $2.4 \mathrm{~mm}$ maximum width, pear-shaped, truncated posteriorly, underside slightly convex. Genital swellings slightly prominent, sclerotized, and close to each other, without distinct medio-terminal swelling between them. Minute sclerotized dots close to genital swellings not observed. Males and copepodids present close to genital swellings. Ovisacs short and thick, terminally rounded, up to $2.3 \mathrm{~mm}$ in length and $1.5 \mathrm{~mm}$ in width. Stalk distinct, emerging from underside of ectosoma, clearly displaced to anterior area. Sclerotized ring present; cleared in lactic acid showing border with minute filiform process (Fig. 4A). Endosoma oblong, without ramifications, but with two wide lateral expansions; main body of endosoma more or less circular in cross section, tapering towards end, twisted around intestine of host, usually with short additional coil close to end; ending in small knob, opening to interior of host by minute pore, $0.07 \mathrm{~mm}$ in diameter (Figs. 4B-D).

Young female (Fig. 3D) with typical pear-shaped ectosoma, $1.8 \mathrm{~mm}$ in length. Genital apertures rudimentary, probably not functional. Stalk displaced to anterior zone. Endosoma with lateral expansions less developed than adult females, main endosomal body incompletely surrounding intestine host.

Male (Figs. 2F-H, 5-6). Body elongated, 0.28 $\mathrm{mm}$ in length and $0.1 \mathrm{~mm}$ in width, obscurely segmented, especially in posterior region, without appendages, spermatophores visible through cuticle. Cephalosome wider than metasome-urosome, attached to female body by anterior oral part by a sticky secretion. On ventral surface of urosome, pair of globular projections distinct, as illustrated by Lützen (1964, Figs. 28, 29). Caudal rami represented by two spiniform processes hooked distally, 0.06 $\mathrm{mm}$ in length. Oral appendages difficult to interpret, without mouth opening, 2 pairs of denticulated triangular elements (the inner longer), pair of marginal bifid elements, and pair of tubular and flaccid tubes that could be interpreted as spermiducts (?). Internally, in oral area is pecten-like of uncertain 


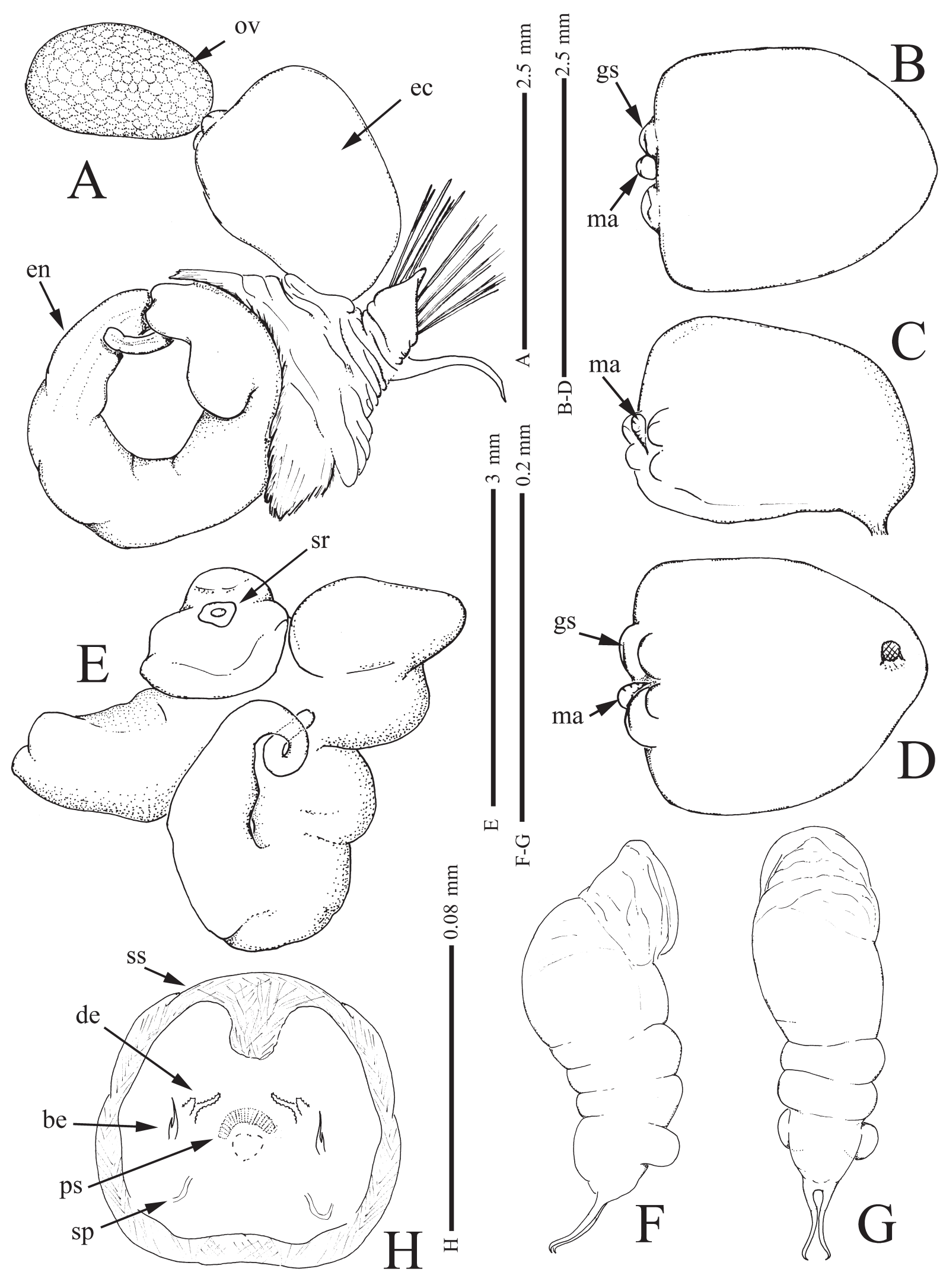

FIG. 2. - Eurysilenium australis sp. nov. A, adult female, with part of the polychaete host surrounding attachment area; B-D, ectosoma of adult female in dorsal, lateral and ventral view respectively; E, endosoma of adult female; F-G, adult male in lateral and dorsal view respectively; $\mathrm{H}$, oral area of adult male. 

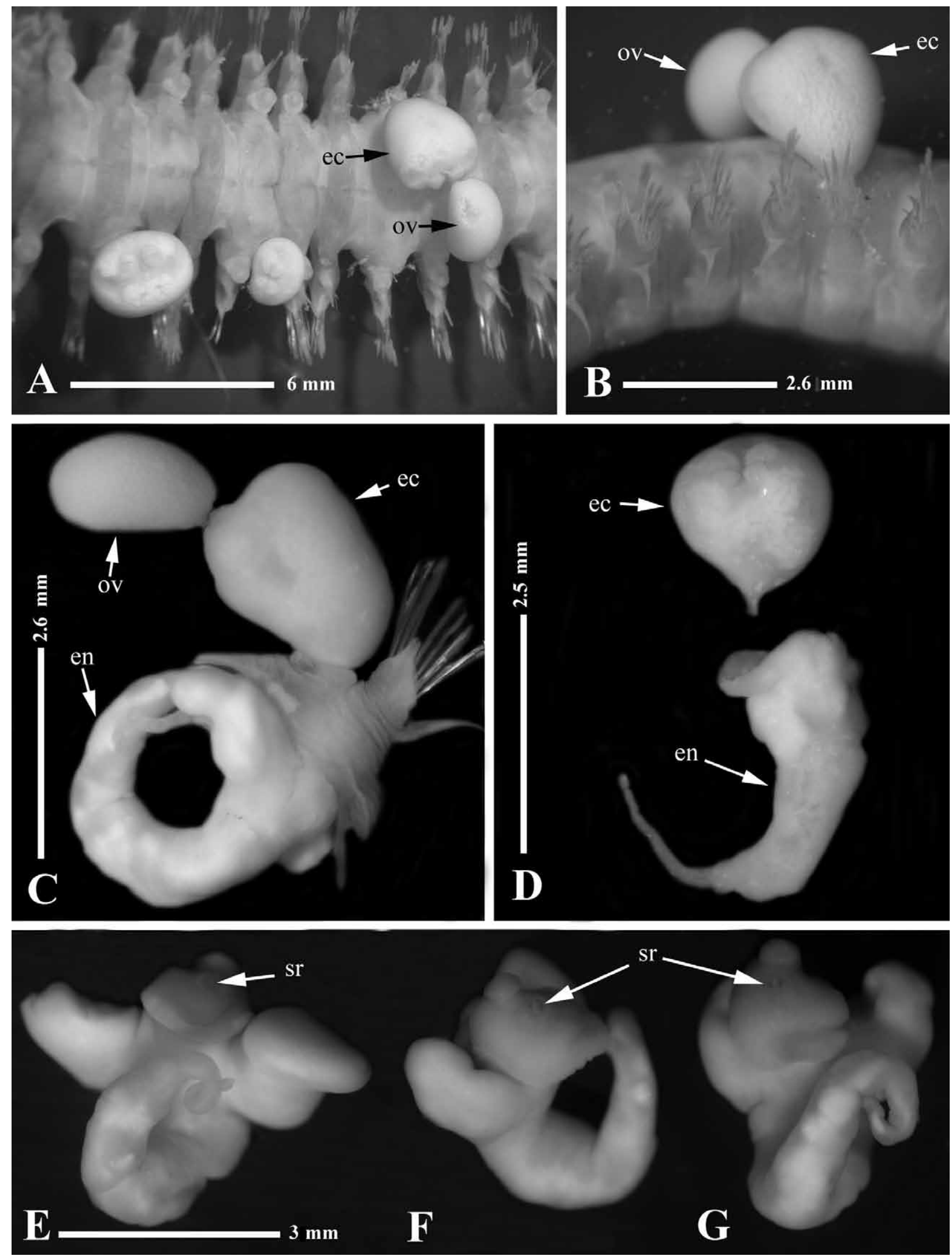

Fig. 3. - Eurysilenium australis sp. nov. A,B, two adult females and a young female attached to their polychaete host; C, adult female removed from the host body, but still with some residue of the attachment area of the polychaete; D, young female removed from the host, ectosoma and endosoma were separated during dissection; E-G, different views of the endosoma of adult females. 

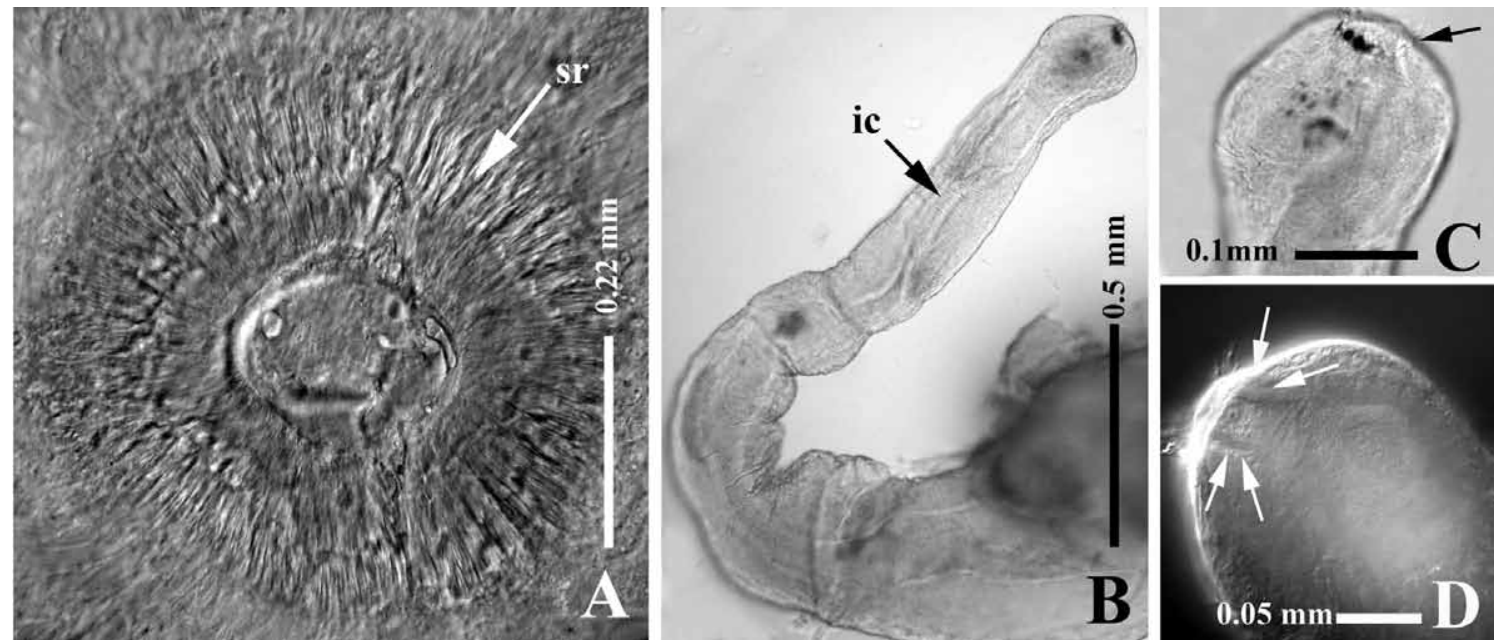

FIG. 4. - Eurysilenium australis sp. nov. Adult female: A, sclerotized ring; B, distal part of endosoma showing internal canal; C,D, detail of the distal part of endosoma, showing terminal pore (arrowed in C) and terminal portion of the canal (arrowed in D) connecting with the exterior (inner spaces of the host) through the distal pore.
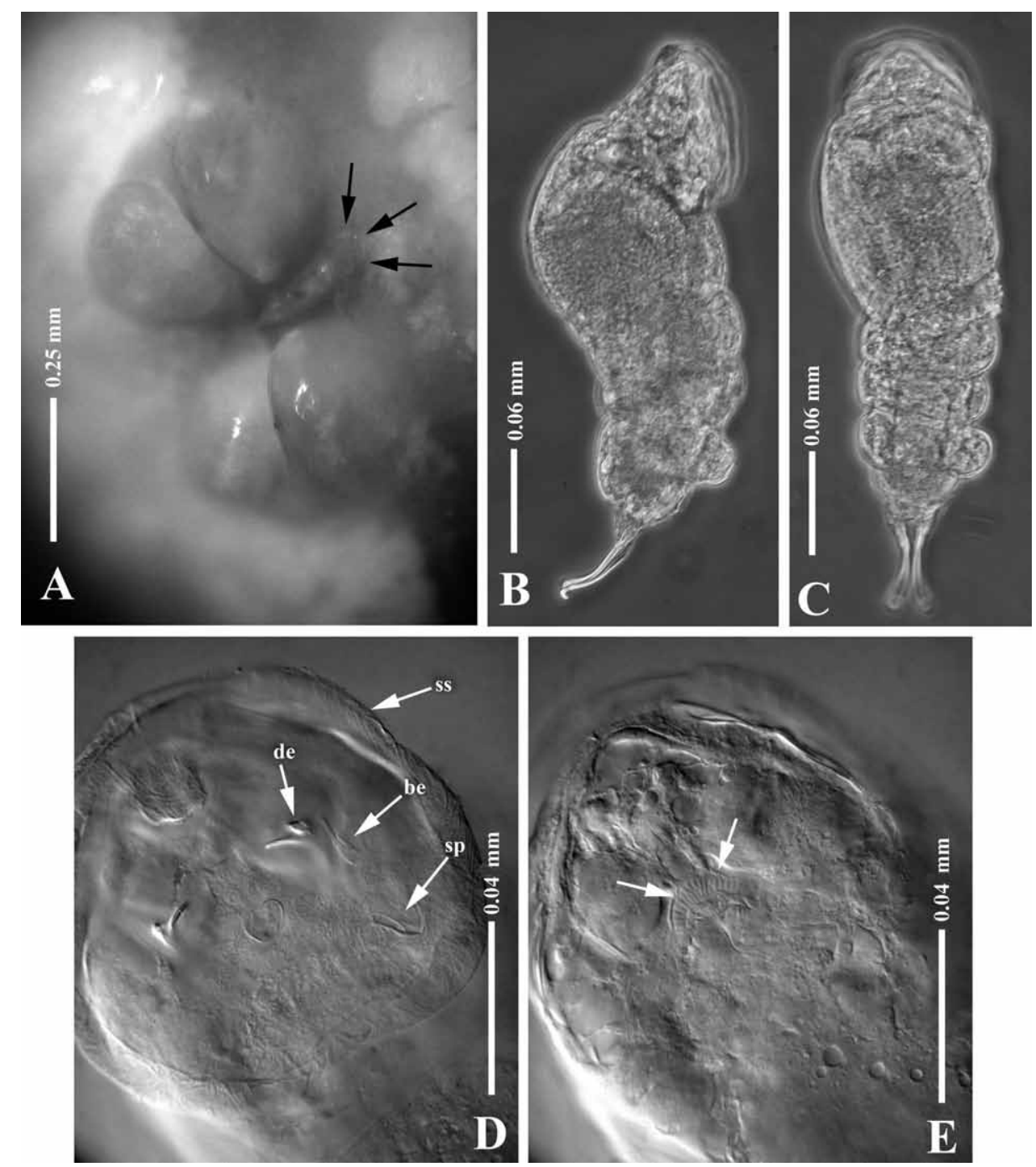

FIG. 5. - Eurysilenium australis sp. nov. Adult female: A, genital area showing genital swellings and a male (arrowed) attached between them. Adult male: B-C, in lateral and dorsal view respectively; D-E, oral area of adult male in surface and lower focus level respectively, pectenlike structure from arrowed in E. 

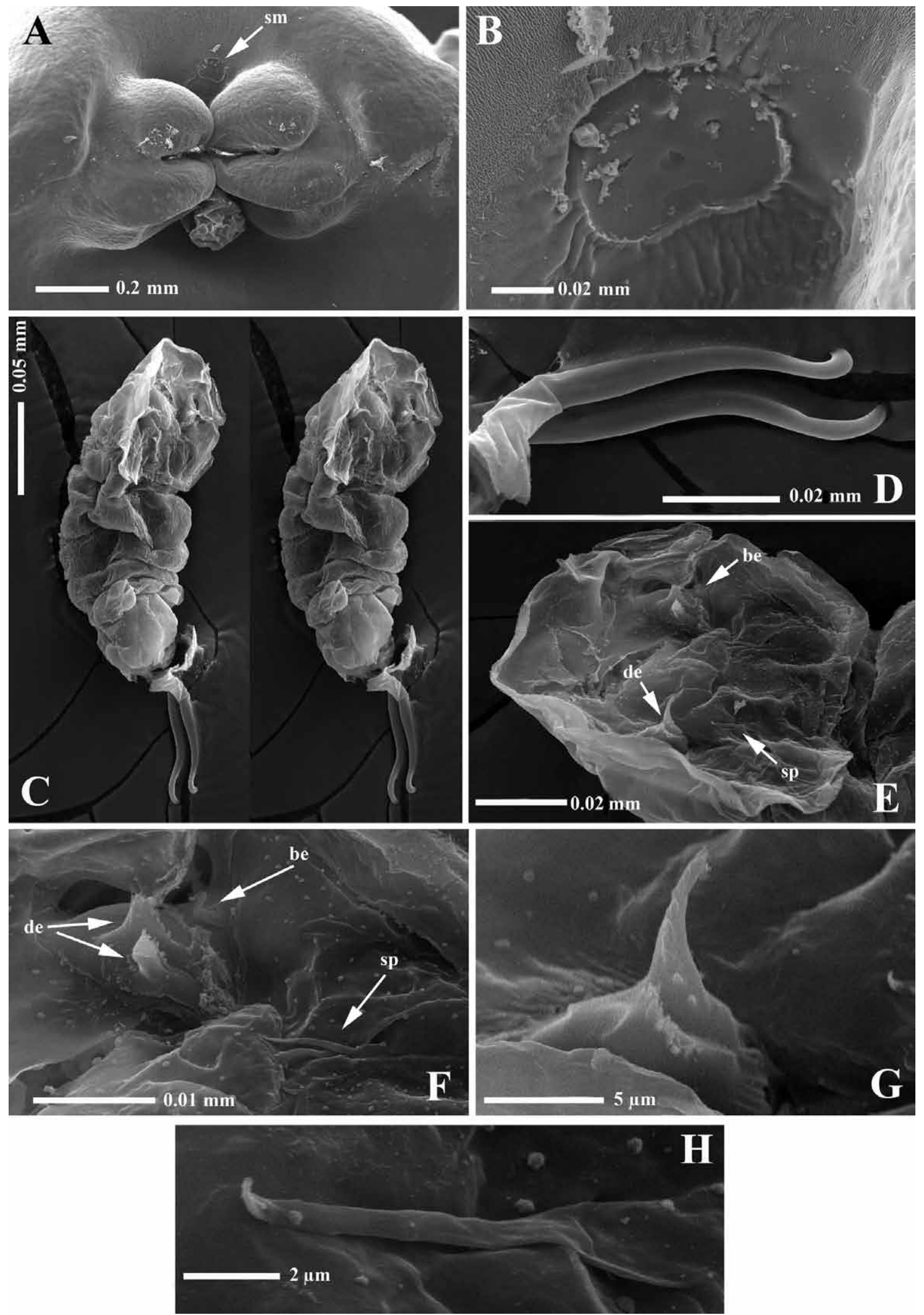

FIG. 6. - Eurysilenium australis sp. nov. Adult female: A, genital area showing genital swellings and a male (collapsed, under genital swelling) and recent scar (arrowed) produced by male's attachment. Adult male: B, male's attachment scar arrowed in A; C, male, lateroventral view, stereo pair; D, detail of the hooked caudal rami; E, detail of oral area; F, detail of left-oral-area elements; G, detail of denticulated triangular elements arrowed in E; $\mathrm{H}$, detail of spermiduct (sp) arrowed in E. 

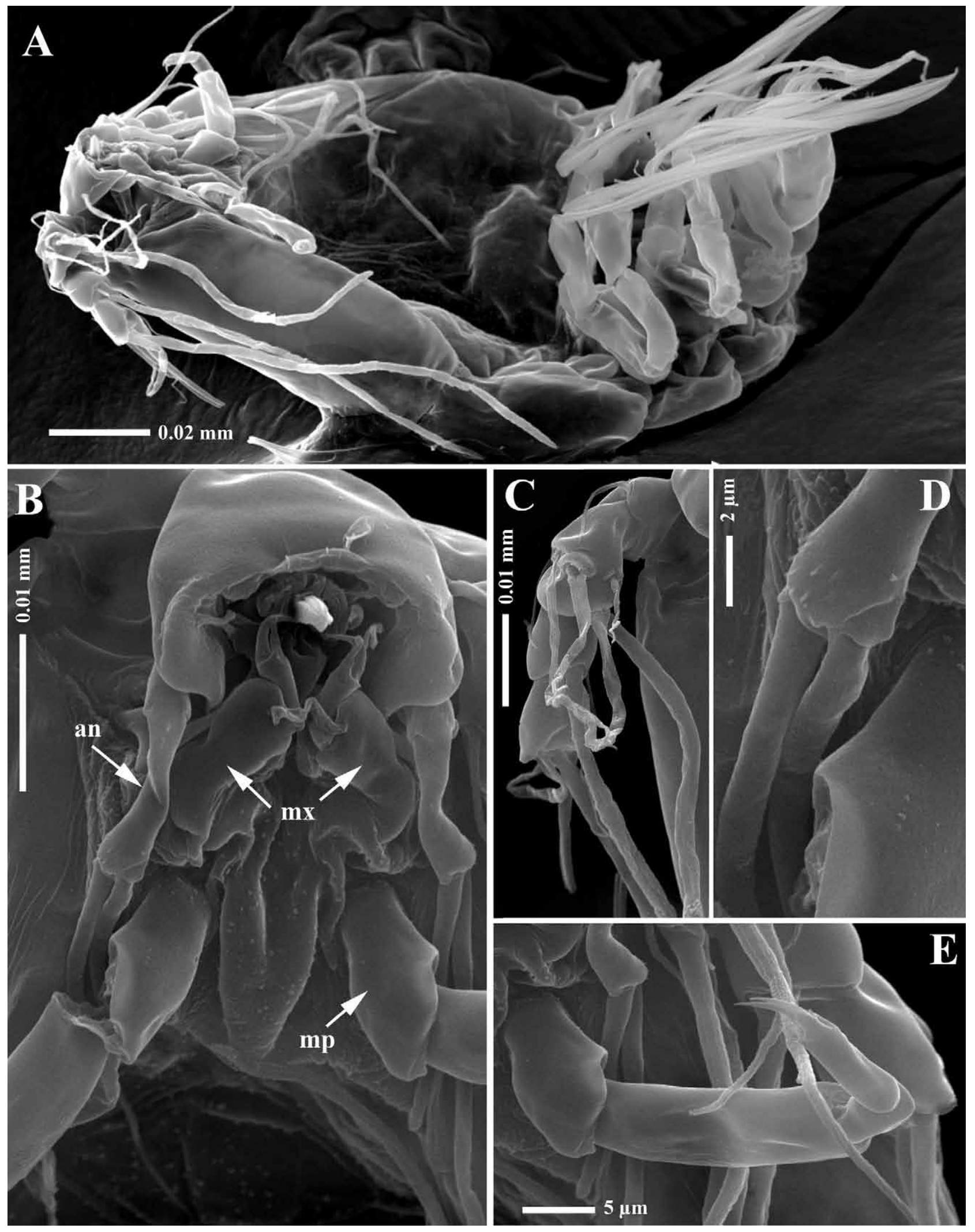

FIG. 7. - Eurysilenium australis sp. nov. Copepodid: A, whole specimen in lateroventral view; B, oral area; C, antennule; D, distal antennular segment; E, maxilliped. 

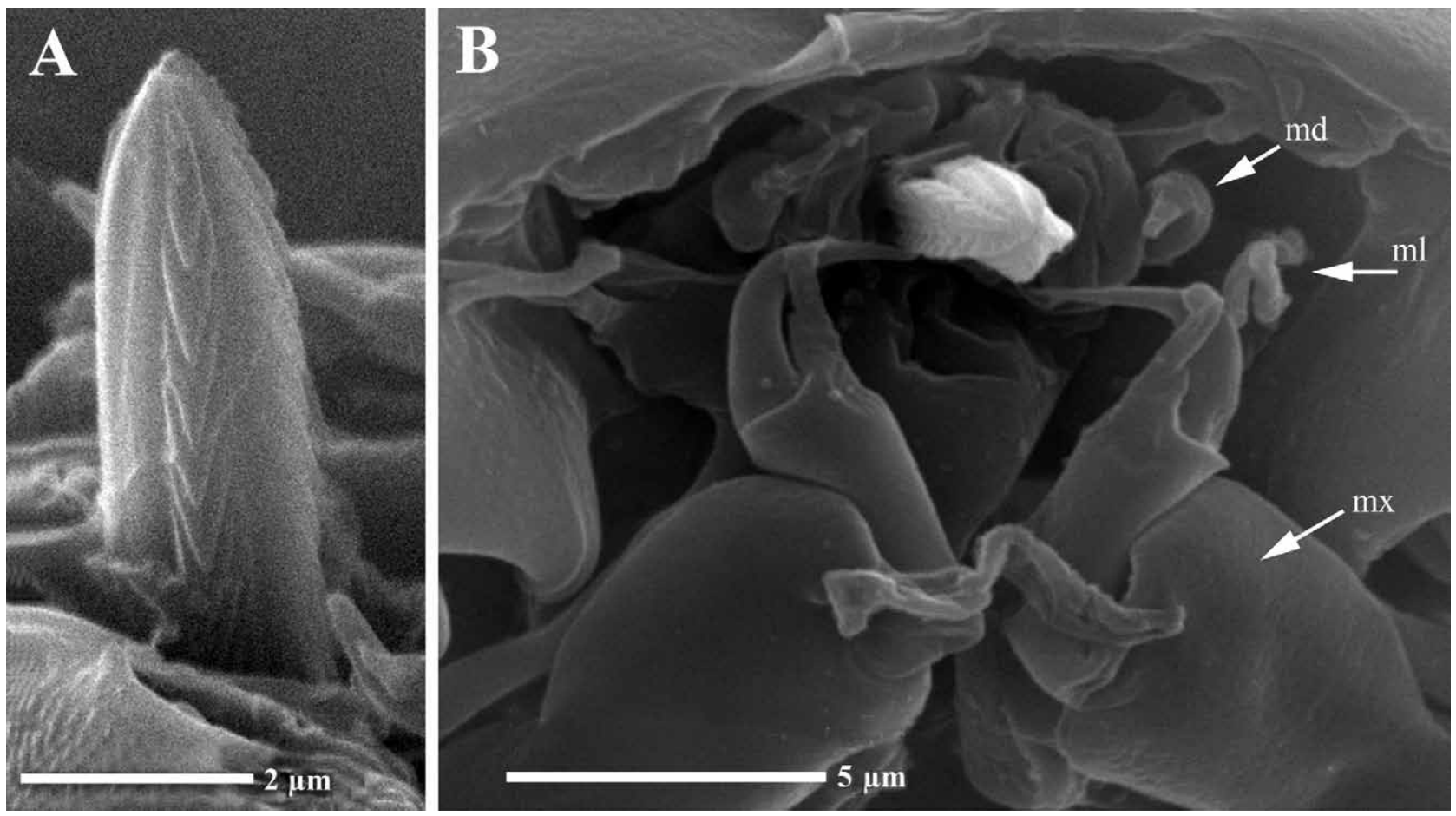

FIG. 8. - Eurysilenium australis sp. nov. Copepodid: A, detail of the denticulate oral stylet; B, detail of the oral area, showing central stylet, and (arrowed) mandible, bifid maxillule (?), and well developed subchelate maxilla.

homology (see Fig. 5E). Males attached to region above the female's genital swellings. Attachment of males produces scars on the female's surface that correspond with outline of the anterior sticky secretion borders (see comparatively Figs. 5D and 6B).

Copepodid (Figs.7-8). Description based on two exuviae (one observed by LM and the other by SEM). General body structure as illustrated by Lützen for Eurysilenium oblongum (1968, fig. 3f-o); $0.20 \mathrm{~mm}$ in length and $0.08 \mathrm{~mm}$ in width. Antennule obscurely 4-segmented, first segment with seta, and total of three aesthetascs visible. Antenna 2-segmented, first segment short, unarmed, second segment about 4.5 times longer than wide, with minute spinules distally and 2 long naked setae. Prominent stylet with serrate lateral surfaces present in oral area, about $5.5 \mu \mathrm{m}$ in length and $2 \mu \mathrm{m}$ in width. Mandibles here interpreted as wide basal segment and distal setiform process. Two setiform elements close to mandible could represent reduced maxillule. Maxilla well defined, 2-segmented, subchelate, with large claw (see Figs. 7B, 8B), first segment with apparently modified seta or secretory tube(?). Maxillipeds 4segmented, last segment with two claw-like elements (Fig. 7E). Segmentation and armature of legs and caudal rami as described by Lützen (op. cit.) for $E$. oblumgum, except endopodal seta of leg 2 , is barbed, and inner endopodal seta of leg 3 , is less densely barbed than those illustrated by Lützen.

Position on host (Figs. 3A, B). In the two polynoids studied, all females were attached dorsally, between the parapodia, with posterior part of ectosoma towards the mid-dorsal axis of polychaete.

Etymology. The species is named after the geographical area where it was found.

\section{Genus Gottoniella gen. nov.}

Diagnosis. Adult female with ectosoma laterally expanded; sclerotized ring present in stalk, between ectosoma and endosoma, just below host surface; endosoma largely bifurcate, both tubular extensions embracing intestine of host, each endosomal branch with single linear internal canal, mouth or clear communication between internal canal and exterior not observed, although endosomal surface is irregular with numerous pores and groups of hair-like structures. Adult male transformed, slightly curved ventrally; cephalosome distinguishable, with bilobed ventral shield and 3-segmented maxillipeds(?); urosome enlarged posteriorly with lateral swellings, ending in bifurcate pointed process. Associated with polynoid polychaetes. 


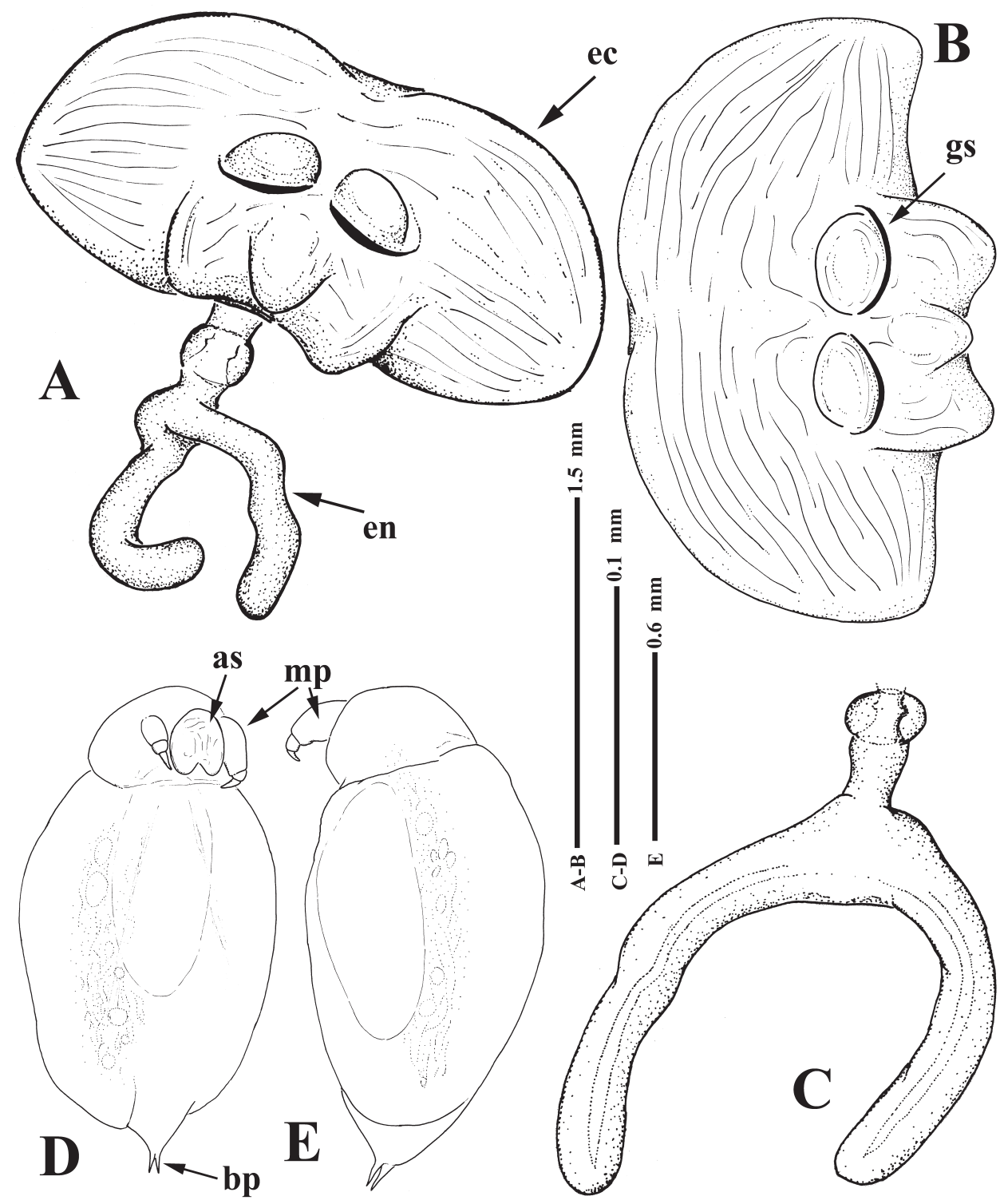

FIG. 9. - Gottoniella antarctica gen. et sp. nov. A, adult female, postero-dorsal view; B, adult female ectosoma, dorsal view; C, adult female endosoma lateral view; D-E, adult male in ventral and lateral views respectively.

Type species. Gottoniella antarctica, sp. nov., here designated.

Etymology. The new genus Gottoniella, is named in honour of the naturalist Vivian Gotto, in recognition of his contribution to carcinology, especially concerning our knowledge of symbiotic copepods.

\section{Gottoniella antarctica sp. nov.}

(Figs. 9-13)

Material examined. ZIZMH (K 40876), holotype, one adult female, parasitizing one specimen of Harmotho sp. (Polynoidae), Polarstern cruise ANT XIX/5 (LAMPOS), stn 223, Discovery
Bank, Scotia Sea, 608.16'S 34 ${ }^{\circ} 55.59^{\prime} \mathrm{W}, 374.2-378.6$ m depth, 5 April 2002. ZIZMH (K 40877), allotype, adult male, with the same sampling data as the holotype. BEIM (COP 212) two adult females and one adult male, with the same sampling data as the type material. BEIM (COP 208), one ovigerous female and one young female parasitizing an unidentified polynoid polychaete, BENDEX cruise ANT XXI/2, stn. 65/292-1, Drescher Inlet, eastern Weddell Sea, Antarctica, 7251.43'S $19^{\circ} 38.62^{\prime} \mathrm{W}, 576.4-597.6 \mathrm{~m}$ depth, 31 December 2003. Type host is deposited in ZIZMH (P 24721).

Female (Figs. 9A-C, 10-13). Ectosoma up to 1.5 $\mathrm{mm}$ in length, and $2.8 \mathrm{~mm}$ in width, laterally expanded, crescent-moon-shaped, convex side anteriorly and concave side posteriorly, and pointed posteriorly; surface of ectosoma with moderately-deep longitudinal ridges. Posterior area strongly protruding, with genital swellings heavily sclerotized and vault- 

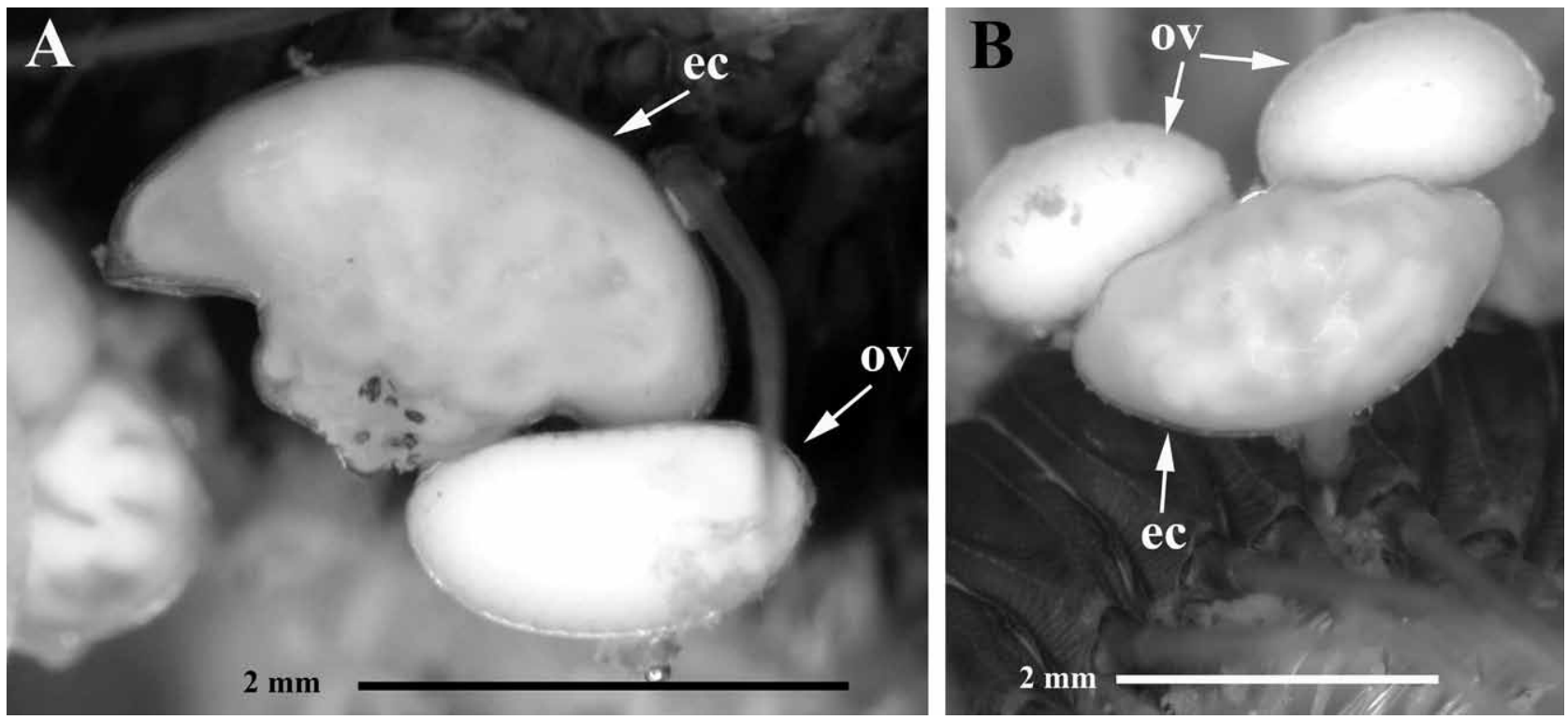

FIG. 10. - Gottoniella antarctica gen. et sp. nov. A-B, dorsal and anterior view of living adult females attached to polychaete host, notice that black spots on the posterior part in A are males attached close to genital swellings.

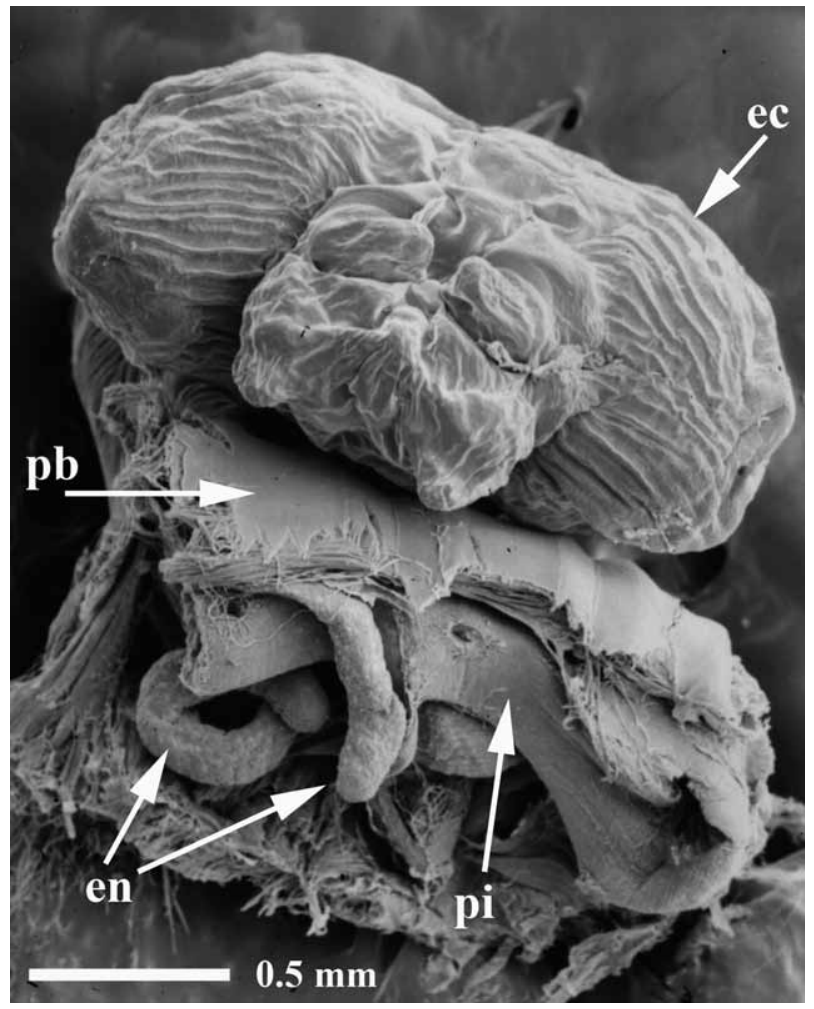

FIG. 11. - Gottoniella antarctica gen. et sp. nov. posterior view of a adult female still attached to its polychaete host. The polychaete has been partially dissected to show both endosomal branches embracing the intestine of the host.

ed; posterior medio-terminal swelling prominent, distinctly directed towards posterior; posterior region ending in two symmetrical and conical projections. Males attached around genital area, producing dis- tinctive scar on female's surface. Ovisac ovoid, terminally rounded, up to $1.9 \mathrm{~mm}$ in length and $1 \mathrm{~mm}$ in width. Stalk connecting ectosoma and endosoma emerging from underside of ectosoma, displaced anteriorly area. Sclerotized internal ring present, bell-shape, with free edge rough (Figs. 13A, B). Endosoma bifurcate with two, more or less-cylindrical, branches (Figs. 9C, 13A), each with single internal linear canal, without mouth or clear communication between internal canal and exterior, although some minute canals are hardly observable distally. Endosomal surface irregular, with numerous pores and groups of hair-like structures mainly on internal surface of branches (Fig. 13F-H). Live female ectosoma white-orange, due to colour of ovarian lobes (white) and mesenchymatous spaces (orange), visible through the transparent cuticle. Preserved mature females and ovisacs white in colour.

Male (Figs. 9D-E). Body transformed, $0.18 \mathrm{~mm}$ in length and $0.1 \mathrm{~mm}$ in width, slightly curved ventrally. Cephalosome distinct dorsally and laterally, with ventral bilobated shield in anterior region and pair of 3-segmented maxillipeds. Posterior end enlarged, with distinct bifurcate pointed process and two lateral swellings. Spermatophores visible through cuticle, slightly displaced anteriorly. Males attached to region above female genital swellings. Attachment of males producing characteristic scar on surface of female with possible marks of maxillipeds and two pores probably produced by sper- 

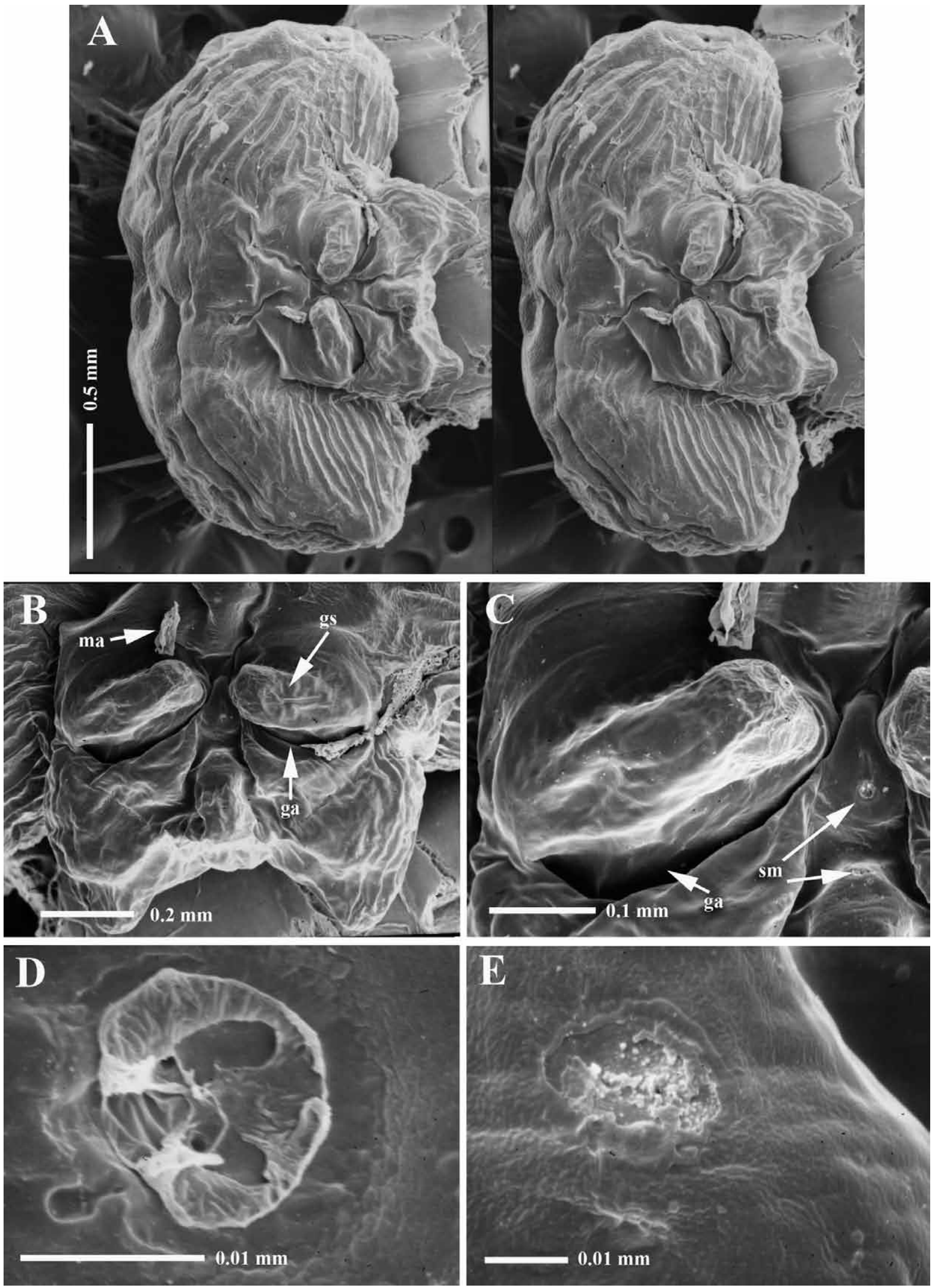

FIG. 12. - Gottoniella antarctica gen. et sp. nov. A, adult female ectosoma in dorsal view, stereo pair; B, detail of posterior part in dorsal view; C, detail of a genital area; D,E, recent and old scars produced by male attachments, notice the two pores (in D) corresponding with the spermiducts of the male. 

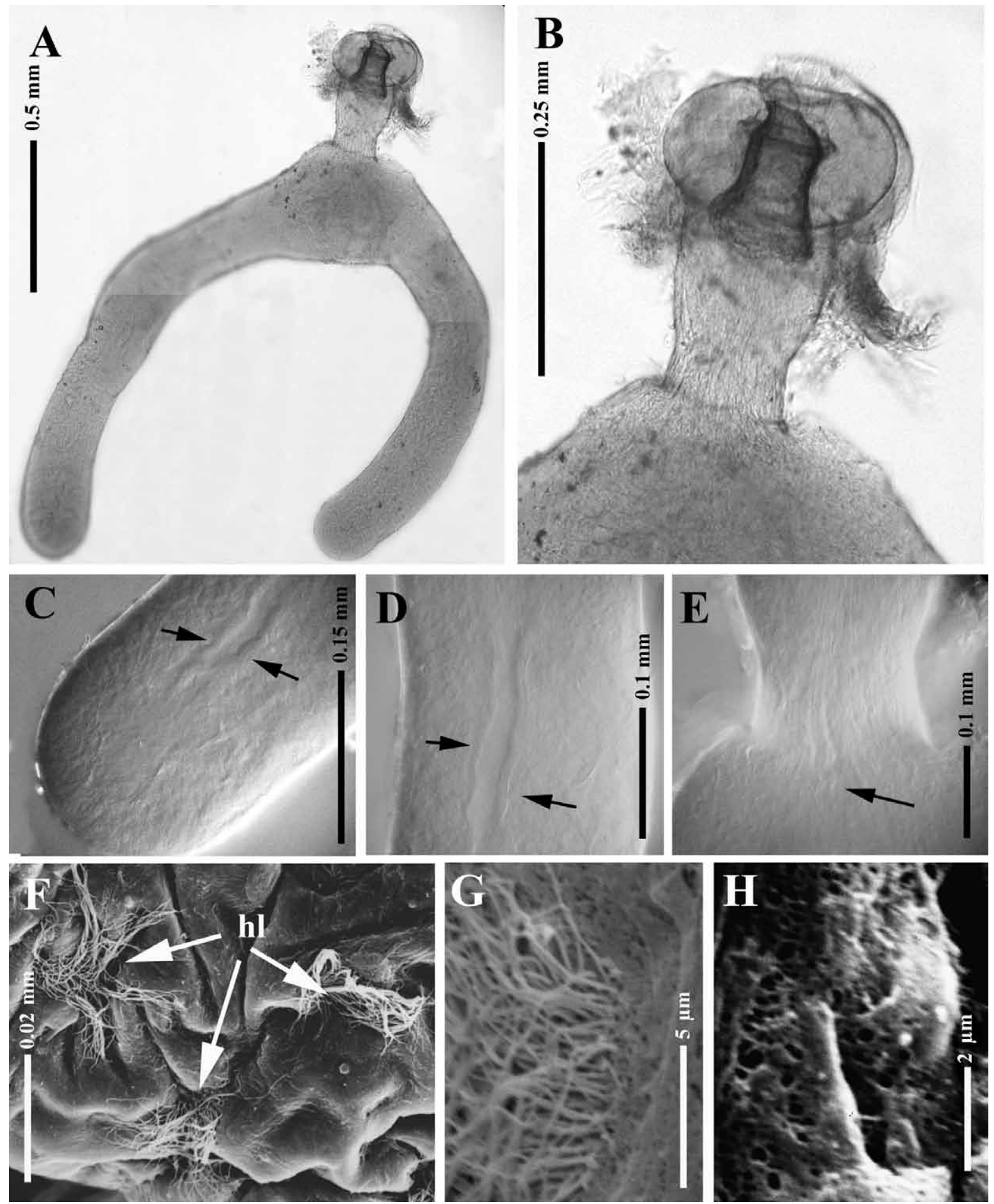

FIG. 13. - Gottoniella antarctica gen. et sp. nov. A, adult female endosoma in lateral view; B, ineck portion under sclerotized ring; C-E, distal, central and proximal parts of the endosoma, showing the well-defined inner channel (arrowed); F-H, surface of adult female endosoma, showing hair-like structures and numerous pores.

miducts (see Figs. 12D, E). Scars of old attachments also observed (Fig. 12E). Live males darker due to colour of central cement gland observable through transparent cuticle. Preserved males similar to live material in colour.
Position on host (Figs. 10, 11). Parasite invariably attached dorso-laterally on polynoid body, with posterior ectosomal part oriented to sagittal plane of symmetry of the polycheate. Both endosomal branches surround the host's gut. 


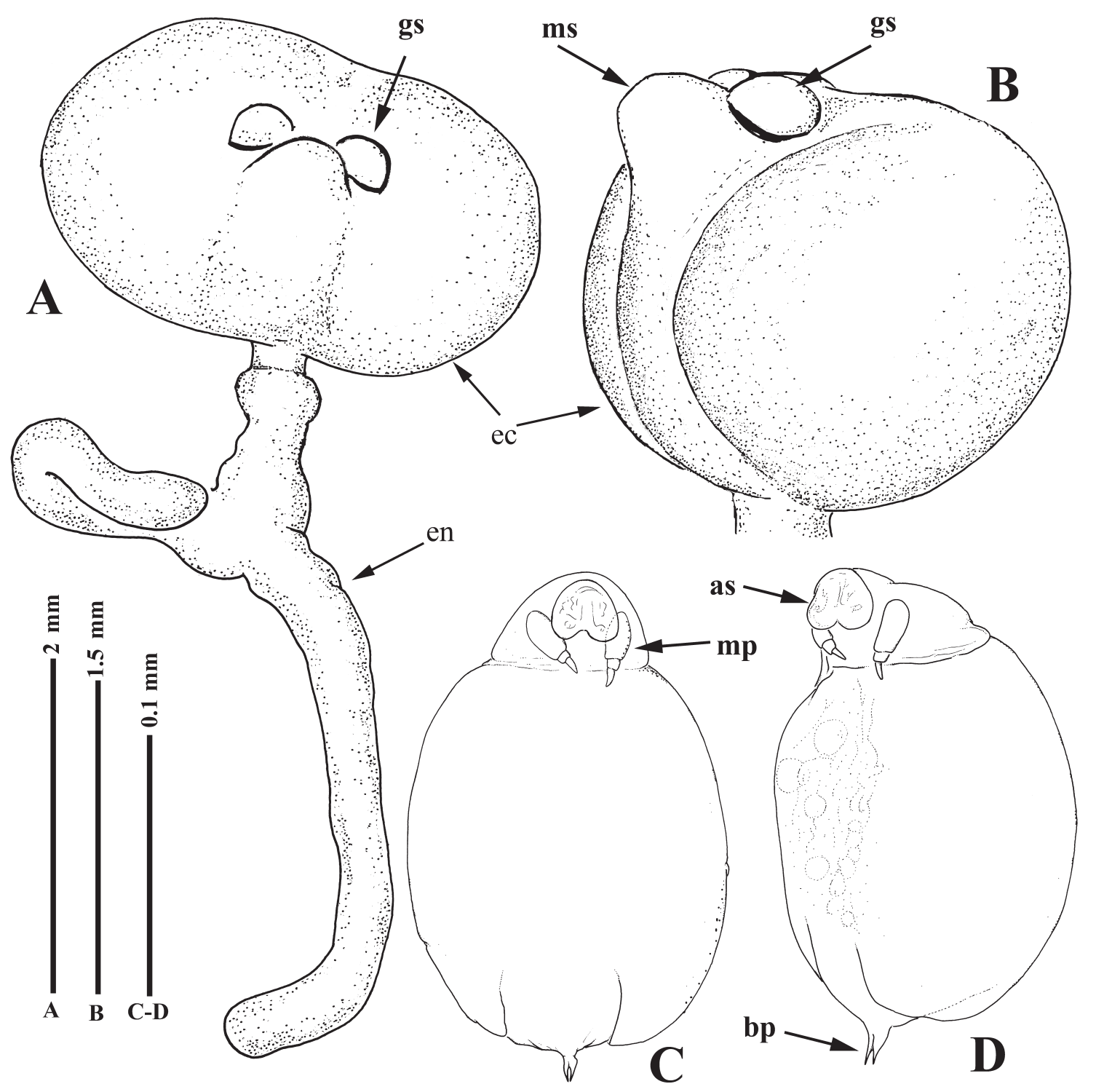

FIG. 14. - Gottoniella andeepi sp. nov. A, adult female, in posterior view; B, adult female ectosoma in latero-posterior view; C,D, adult male in ventral and latero-ventral view.

Etymology. The specific name antarctica refers to the geographic area where it was found.

\section{Gottoniella andeepi sp. nov.}

(Figs. 14-15)

Material examined. ZIZMH (K 40878), holotype, one adult female parasitizing one specimen of Harmothoe sp. (Polynoidae), Polarstern cruise ANT XIX/3 (ANDEEP-I), stn 46-8, North Elephant Island, Scotia Sea, 60³8.79’' 5357.42’W, 2895 m depth, 2 February 2002. ZIZMH (K 40879), allotype, one adult male, with the same sampling data as the holotype. Type host is deposited in ZIZMH (P 24720).

Female (Figs. 14A, B, 15). Ectosoma up to 1.7 $\mathrm{mm}$ in length and $3 \mathrm{~mm}$ in width, globular, laterally bilobed by shallow sagittal valley, resulting in two lateral globoid hemispheres. Underside slightly convex. Laterally without longitudinal ridges. Genital swellings slightly prominent and heavily sclerotized, placed close to each other, with small free space between them. Medio-terminal swelling prominent, conical, most conspicuous structure in ectosoma. Sclerotized dots not observed after light microscope study. Remains of previous ovisacs present. Stalk short, emerging from underside of ectosoma, displaced anteriorly. Genital area, including medio-terminal swelling, widely separated from stalk. Typical sclerotized ring not confirmed due to scarcity of available material. Endosoma bifurcate, each branch elongate and slightly flattened. 


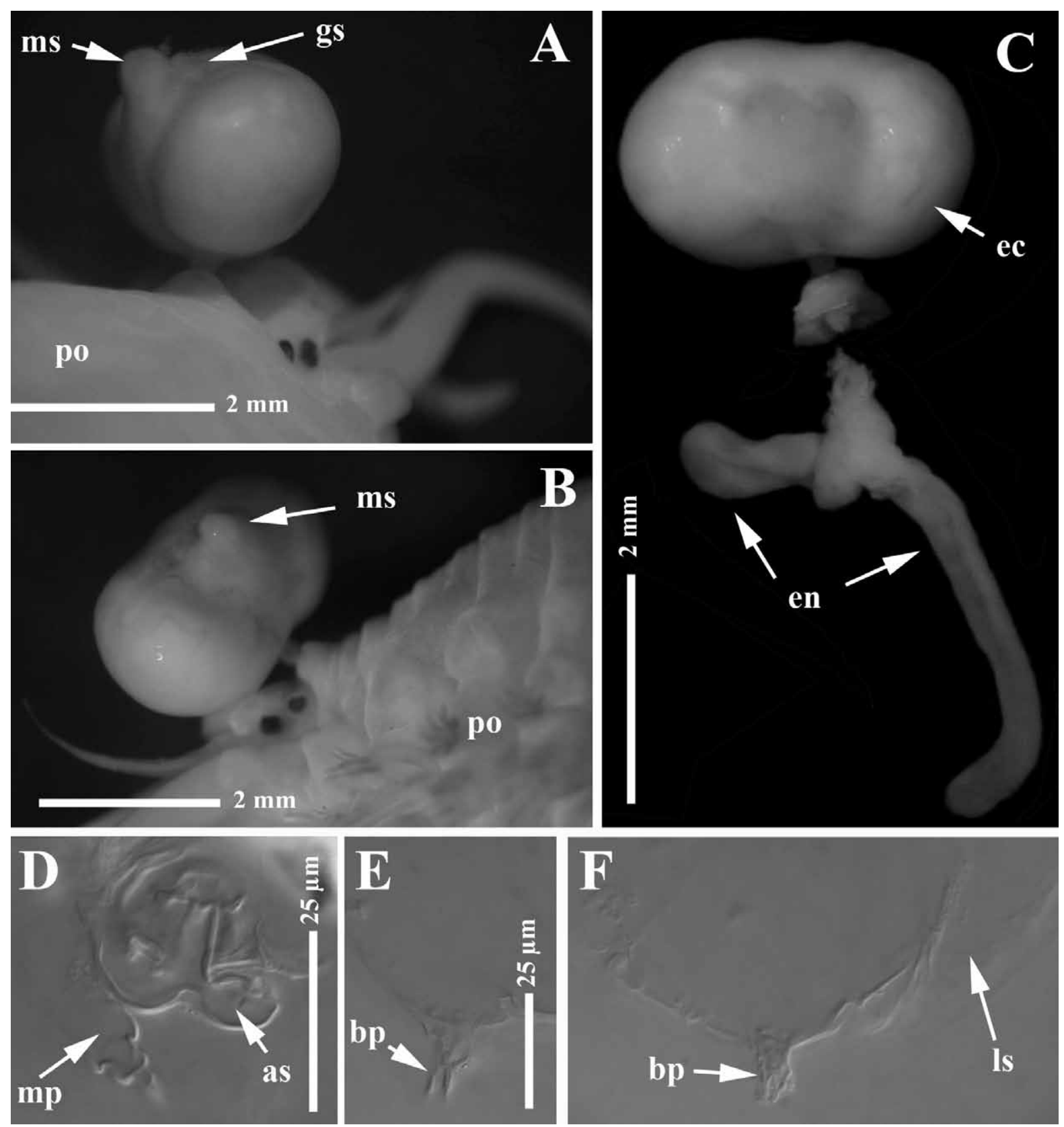

FIG. 15. - Gottoniella andeepi sp. nov. Adult females: A,B, latero-posterior views of the ectosoma still attached to the polychaete host; C, ectosoma and endosoma separated during the dissection of the host; D, antero-ventral shield and maxilliped; E,F, posterior part in two different focus levels showing postero-distal bifurcate pointed process and lateral swellings.

Male (Figs. 14C, D, 15D-F). General structure agrees with that of type species. Body transformed, $0.19 \mathrm{~mm}$ in length and $0.12 \mathrm{~mm}$ in width, slightly curved ventrally. Cephalosome region distinct dorsally and laterally, with ventral bilobed shield in anterior region and pair of 3-segmented maxillipeds(?). Posterior end enlarged, with distinct bifurcate pointed process and two lateral swellings. Spermatophores and cement gland visible through cuticle. Male attached close to female genital swellings.
Position on host (Figs. 15A, B). The single female was found dorsally on the first body segment posterior to the prostomium, on the sagittal plane of the polychaete. One of the endosomal branches was placed posteriorly between the pharynx and the dorsal longitudinal musculature, while the other was folded on itself, and placed on the pharynx.

Etymology. The species is named after the Antarctic research cruise (ANDEEP-I) in which it was collected. 


\section{DISCUSSION}

\section{Taxonomic remarks on the new species of Eurysilenium}

This new species is included in the genus Eurysilenium by the following set of characters: reduced genital areas, endosoma tapering distally and coiled around the host's intestine, with a minute pore distally, and structure of the adult males and copepodids.

The adult females of Eurysilenium australis are clearly distinguishable from the known species by the shape of the ectosoma (pear-shaped, truncated posteriorly), endosoma (with two lateral expansions) and ovisacs (short and thick) (see Lützen, 1964: and present paper). The descriptions of the two last species included in this genus, E. intermedium and E. fungosum (see Stock, 1986, 1996) are incomplete, lacking details concerning the endosoma.

The descriptions of males and copepodids of the two previously described species are not sufficiently detailed for comparative discussion. With the discovery of Eurysilenium antarcticum our knowledge of the oral area of males and copepodids has noticeably improved; however, further details based on additional material are desirable. In the light of the new morphological features discovered in the oral area of Eurysilenium copepodids, a comparative re-examination of Herpyllobius copepodids is needed.

\section{Taxonomic remarks on the genus Gottoniella}

With the description of Gottoniella, four genera are now known in the family Herpyllobiidae. Mature females of Gottoniella can be easily distinguished from the other genera by the general shape of the ectosoma with a tendency to be bilobed laterally, and a largely two-branched endosoma with a distinct central canal, but without a clear distal pore.

Mature males of Gottoniella can be identified by a cephalosome region distinctly separated from the metasome-urosome part, and a pair of 3-segmented maxillipeds(?), which are absent in the males of the other genera in the family (Herpyllobius and Eurysilenium). In addition, males of Herpyllobius are reduced bottle-shaped with an anterior zone not clearly resembling the cephalic area of the copepodid, and a rounded posterior zone (see Jensen, 1900; López-González et al., 2000). Gottoniella retains a cephalic area that is visible dorsally and ventrally, the body is ventrally curved, and the posterior zone is enlarged with two lateral swellings, ending in a medial bifid pointed process that is ventrally oriented; in contrast, the male of Eurysilenium is easily distinguishable by its segmented body and bifurcate posterior end. Mature males of Phallusiella are unknown. Nothing is known about the copepodids of Gottoniella.

In agreement with Lützen (1964) and Gotto (1993), the genus Phallusiella is provisionally maintained awaiting a complete description based on newly collected specimens. Two species currently included in the genus Herpyllobius show a triangular ectosoma with two anterior humps and a stalk attachment clearly displaced to the anterior area, these species are $H$. haddoni Lützen, 1964 and $H$. luetzeni López-Gonzalez and Bresciani, 2001. Although the general shape of the herpyllobiid adult female's ectosoma is considered as a generic character, the current knowledge about the little-studied specimens of adult males of these two species, has not revealed differences with other Herpyllobius species. Only the unusual position of the males of $H$. haddoni as found by Lützen (1964), on the top of the ectosoma a considerable distance from the genital swelling, is worthy of mention. More information, such as the SEM study of additional males and copepodids is needed in order to ascertain whether these two species belong to the genus Herpyllobius or should be placed in a different genus.

Gottoniella species are easily distinguishable from each other by the general aspect of the ectosoma, especially the development of the lateral and posterior areas (see for example Figs. 9 and 14 of the present paper). In spite of the clear ectosomal differences, both species are included in the same genus by the shape of the endosoma (unique in the family) and by the similar structure of the males.

\section{Biogeographical remarks on the Herpyllobiidae}

The members of the family Herpyllobiidae have mainly been reported in high latitudes in both hemispheres (Lützen, 1964; López-González and Bresciani, 2001). Phallusiella is only known from the English Channel, Eurysilenium is known from the Kara Sea, Norway, Skagerrak, west and east Greenland, New Caledonia, Indonesia (see Lützen, 1964; Stock, 1986, 1996), and now from Antarctica, while Herpyllobius is the most widely distributed 
genus, present in both hemispheres, especially in high latitudes with a few records in temperate and tropical waters (see Laubier, 1961; Lützen, 1964). As commented above, Gottoniella is known only from the Scotia Sea and Weddell Sea. Of the 26 known species in the family, Herpyllobius is the most speciose genus with 17 species, followed by Eurysilenium (5 species), Phallusiella (2 species), and Gottoniella (2 species). Moreover, 14 out of the 26 herpyllobiid species are exclusively known in the Southern Oceans, especially in Antarctic waters (see López-González and Bresciani, 2001).

\section{ACKNOWLEDGEMENTS}

We wish to thank Americo Montiel (Universidad de Magallanes, Punta Arenas, Chile) for identifying the polynoid species and providing valuable information for the present paper. The authors acknowledge the valuable assistance of the officers and crew of the Polarstern, and many colleagues on board during the ANDEEP-I, LAMPOS and BENDEX cruises. Thanks to the cruise leaders and steering committee of the cruises (especially Dieter Fütterer and Angelika Brandt in ANDEEP-I; and Wolf E. Arntz and Josep-M. Gili in LAMPOS and BENDEX), who kindly facilitated the work on board and for the chance to collaborate in these Antarctic programmes.

Special thanks are also due to Neus Vert, Estefanía Rodríguez, and James A. Blake (Marine and Coastal Center, Woods Hole, Massachusetts) for their valuable assistance during the ANDEEP-I, LAMPOS and BENDEX cruises. Support for this work was provided by the Spanish CICYT projects REN2001-4269-E/ANT and REN2001-4929E/ANT, and REN2003-04236. Tony Krupa is thanked for reviewing the English version. The authors are also thankful for the comments and suggestions given by two anonymous referees.

This is ANDEEP publication $n^{\circ} 49$.

\section{REFERENCES}

Boxshall, G.A. and S. Halsey. - 2004. An introduction to copepod diversity. The Ray Society, London: Pp I-XV, 1-966.

Gravier, C. - 1912. Sur l'habitat d'un Crustacé parasite annélidicole (Herpyllobius arcticus Steenstrup et Lütken). Bull. Mus. Hist. nat. Paris, 18: 30-33.

Gravier, C. - 1913. Crustacés parasites. 2 e Expéd. Antarct. Fr. Sci. Nat. 1913(1): 27-77.

Gotto, V. - 1993. Commensal and Parasitic Copepods associated with Marine Invertebrates (and whales). Synopses of the British Fauna (New Series) (eds. Kermack, D.M., R.S.K. Barnes and J.H. Crothers), No. 46. The Linnean Society of London, Universal Book Services / Dr. W. Backuys.

Jensen, S. - 1900. Nogle oplysninger om Rhizorhina ampeliscae H.J.H., Herpyllobius arcticus Stp.-Ltk. og Fam. Herpyllobiidae H.J.H. K. Danske vidensk. Selsk. Forh., 1900(1): 61-112.

Laubier, L. - 1961. Contribution à la faunistique du coralligene, V. Herpyllobius arcticus Steenstrup et Lütken, copépode parasite d'annélide polychètes en Méditerranée occidentale. Vie Milieu, 12: 261-268.

López-González, P.J. and J. Bresciani. - 2001. New Antarctic records of Herpyllobius Steenstrup and Lütken, 1861 (parasitic Copepoda) from the EASIZ-III cruise, with description of two new species. Sci. Mar., 65(4): 357-366.

López-González, P.J., J. Bresciani and M. Conradi. - 2000. Two new species of Herpyllobius Steenstrup and Lütken, 1861 and a new record of Herpyllobius antarcticus Vanhöffen, 1913 (parasitic Copepoda) from the Weddell sea, Antarctica. Pol. Biol., 23: $265-271$.

Lützen, J. - 1964. A revision of the family Herpyllobiidae, (Parasitic Copepods) with notes on host and distribution. Ophelia, 1: 241-274.

Lützen, J. - 1966. The anatomy of the family Herpyllobiidae (Parasitic Copepods). Ophelia, 3: 45-64.

Lützen, J.-1968. On the biology of the family Herpyllobiidae (Parasitic Copepods). Ophelia, 5: 175-187.

Lützen, J. and B. Jones. - 1976. Two new species of Herpyllobius (Parasitic Copepoda) from New Zealand and the Antarctic. New Zeal. J. Mar. Fresh. Res., 10(2): 371-374.

Stock, J.H. - 1986. Cases of hyperassociation in the Copepoda (Herpyllobiidae and Nereicolidae). Syst. Parasit., 8: 71-81.

Stock, J.H. - 1996. Two new species of copepoda parasitic on polynoid polychaetes. Crustaceana, 69(4): 438-445.

Vanhöffen, E. - 1913. Herpyllobius antarcticus n. sp., ein an Enipo rhombigera Ehlers schmarotzender Copepode. Dtsch. Südpol.Exped., 13(5): 599-602.

Scient. ed.: D. Martín

Received January 28, 2005. Acccepted October 11, 2005. 
